\title{
CHEMICAL POLLUTION AND SEAFOOD SAFETY, WITH A FOCUS ON MERCURY: THE CASE OF PEARL RIVER DELTA, SOUTH CHINA
}

Ming-Hung Wong (minghwong@ied.edu.hk)

Consortium on Health, Environment, Education and Research (CHEER), and Department of Science and Environmental Studies, The Hong Kong Institute of Education, Tai Po, Hong Kong, PR China; School of Environment, Jinan University, Guangzhou, PR China

\section{ABSTRACT}

Most of the fish consumed in Hong Kong are farmed fish, including freshwater and marine fish, which are highly susceptible to various chemicals discharged from industrial sites nearby. It is recognized that emissions from coal-power plants are major sources of $\mathrm{Hg}$ in the environment worldwide. The situation is serious in the Pearl River Delta, South China, with a high demand of electricity, to support rapid development of various industries. In addition, the area has become the world's manufacturer for electrical/electric equipment, textiles, footwear, furniture, etc., emitting a wide range of toxic chemicals into the environment. In fact, "chemical food contaminants" is one of the 3 key global food safety concerns. Food safety is any action and policy which ensure food is safe, in the entire food chain, i.e. from production to consumption (WHO, 2013). This article attempts to review environmental health issues related to persistent toxic substances (PTS), with a focus on $\mathrm{Hg}$; from biogeochemistry, ecology, epidemiology, to policy and management, citing examples related to South China.

Key Words: Emerging chemicals of concern; Fish contamination and human health; Mercury; Pearl River Delta; Persistent toxic substances

\section{INTRODUCTION}

The present article focuses on human health risks due to consumption of fish contaminated by persistent toxic substances (PTS), focusing on mercury (Hg). Minamata disease reported in 1950s and 1960s was in fact acute Hg poisoning of residents of Minamata Bay (a fishing village), Japan, who had consumed contaminated finfish and shellfish from the bay, resulted in several hundred deaths. This was due to the discharge of $\mathrm{Hg}$ from an industrial source, and under anaerobic condition, sulfide reduction bacteria were able to transform inorganic $\mathrm{Hg}$ to methyl $\mathrm{Hg}(\mathrm{MeHg}$ ), the most toxic form of organic $\mathrm{Hg}$, which was subsequently taken up by these seafood, a nd hence the problem. It was apparent that the neurotoxicological effects on fetal development from pregnant women consuming $\mathrm{Hg}$ laden seafood could be serious (Harada, 1995).

Food safety is in fact one of the current major public health issues in the world, especially in the developing countries. Repeating the episodes happened in the $18^{\text {th }}, 19^{\text {th }}$ and $20^{\text {th }}$ centuries in developed countries, much damage has done to the environment in developing countries, at a 
much faster rate, due to rapid population growth, urbanization and industrialization. Such damage further leads to soil/sediment, water and air pollution, accompanied with a variety of problems including release of toxins and carcinogens.

Under such circumstances, soil/sediment will become a sink or even a source of pollutants, threatening its ability to meet safety standards, and jeopardize food production. This is especially true for aquaculture, where the cultivated fish (including pond fish culture and mariculture, along coastal areas) is contaminated, due to contamination of various PTS, including heavy metals and persistent organic pollutants (POPs). Furthermore, the use of trash fish (small fish, without any commercial value), and to certain extent, feed pellets which contain a large portion of fishmeal (mainly made from trash fish) also aggravated the problem, as trash fish is very often contaminated.

This article attempts to review the current status of environmental contamination in the Pearl River Delta (PRD), the most developed region in the whole of China, concerning various pollutants (focusing on $\mathrm{Hg}$ ) detected in different ecological compartments, their effects on different biota, transfer in aquatic food chains, and linkages with potential health risks. The possibility of easing the problems, via the establishment of a regional list of PTS for better control, and relevant regulations and policy are provided.

\section{PERSISTENT TOXIC SUBSTANCES (PTS)}

\subsection{Types of PTS}

Persistent Toxic Substances (PTS) included the original 12 persistent organic pollutants (POPs) listed in the Stockholm Convention control list. These included 9 organochlorine pesticides: Aldrin, endrin, dieldrin, chlordane, dichlorodiphenyltrichloroethane (DDT), hepatachlor, mirex and hexachlorobenzene; 2 industrial chemicals: hexachlorobenzene $(\mathrm{HCH})$, and polychlorinated biphenyls (PCB), and 2 unintended by-products: dioxins (PCDDs) and furans (PCDFs). Nine new POPs were subsequently included in the control list: pentabromodiphenyl ether (PBDE), chlordecone, hexabromobiphenyl, lindane, perfluorooctane sulfonate, octabromodiphenyl ether (PBDE), pentachlorobenzene, short-chained chlorinated paraffins, alpha hexachlorocyclohexane, and beta hexachlorocyclohexane (UNEP, 2015). Each country which signed the legally binding treaty has to prepare an implementation plan to stop producing and using these chemicals. Furthermore, polyaromatic hydrocarbons (PAHs) are generated from industrial combustion and opening burning processes, but not included in the control list.

The Global Report of the project "Regionally based assessment of PTS", organized by the United Nation Environmental Program (UNEP) and funded by Global Environment Facility (GEF) also included organo-metallic compounds such as organotin, organomercury and organolead as PTS, in reviewing the world status of POPs. They also shared the same characteristics as POPs, of being persistent, toxic, bioaccumulative and able to travel long distances through different media (Wong 
et al, 2002; Whylie et al, 2003). In fact, some heavy metals such as cadmium (Cd), copper (Cu), lead $(\mathrm{Pb})$, and zinc $(\mathrm{Zn})$, and metalloids such as arsenic (As) are also very persistent, and included as PTS. Persistent toxic substances also included some emerging chemicals of concern (ECCS). Some of these chemicals were regarded as safe when they entered the market, but eventually long-term environmental and health effects have been noted. A very good example is PBDE (flame retardants), an ECC, which has been included in the POPs control list, only a few years ago. Other ECCs included phthalates, bisphenol A, PFOA/PFOS, pharmaceutical and health care products (PCPPs), nanoparticles, etc. (Wong et al, 2012).

\subsection{PTS Emitted to the Environment are Found in Human Body}

These chemicals are emitted to the environment through different activities and sources, from domestic, industrial and agricultural runoff. They will eventually enter into our sewage treatment systems, which were intended for breaking down organic matter into inorganic matter via aerobic and/or anaerobic bacteria. There is a possibility of some of these PTS entering into food chains through the discharge of sewage effluent into the water bodies, and through application of sewage effluent and sewage sludge for crop growth. Our recent studies (commissioned by the Drainage Services Department) attempted to investigate the removal efficiencies of a wide range of PTS (including major POPs, heavy metals, antibiotics, hormones, etc. in two types of sewage treatment systems: conventional biological treatment, and enhanced chemical treatment, available in Hong Kong. In general, results indicated that the removal efficiencies of different PTS in sewage treatment plants are varied widely. Results on PBDEs showed that once emitted into the environment, these chemicals will be circulated in the ecosystem, may be in other forms (congeners), sometimes even more toxic, finding their ways into human bodies (Man et al, 2015).

The Environmental Working Group (EWG, 2005), based on investigation at 2 major laboratories (AXYS Analytical Services at Sydney and Flett Research Ltd at Winnipeg) identified the average of 200 industrial compounds and pollutants (total 287 chemicals) in 10 newborn babies (through the analyses of umbilical cord blood) both in August and September 2004 in the US hospitals (collected by the Red Cross). These included organochlorine pesticides (DDT, dieldrin, etc.), chemicals used in a wide range of consumer products (PFOA and PFOS), PBDE, PCBs, and chemical pollutants from waste and fossil fuel combustion (PAHs, polychlorinated and polybrominated PCDDs/FCDDs, polychlorinated naphthalenes, $\mathrm{Hg}$ ). Out of the 287 chemicals detected, it is known that 180 cause cancer in humans or animals, 217 are toxic to the brain and nervous system, and 208 cause birth defects or abnormal development based on animal tests. Since then a number of relevant studies has been conducted, confirming the widespread phenomena of PTS entering into human bodies, through the analyses not only cord blood, but also blood and milk of pregnant women.

\section{THE PEARL RIVER DELTA (PRD), SOUTH CHINA}

\subsection{Pearl River Delta in the Past}

The region has been known as "Homeland for Rice and Fish" in the past, due to its abundant water 
resource, fertile soil and favourable (subtropical) climatic conditions. A large part of swamps around PRD has been reclaimed for productive use some six centuries ago. This is the dyke-pond system prevalent in PRD, with a more efficient transfer of nutrients and energy. The dykes facing the sea possess slice gates, which can be opened during high tides, and the fish and shrimps are kept and reared in ponds after the gates are closed. Polyculture is commonly practiced by growing different species of freshwater fish (such as grass carp, mud carp, tilapia and grey mullet), in the same pond with wastes (such as digested pig manure and grass clippings) serving as the major energy inputs (Wong et al, 2004).

Different fish species possess different feeding modes. Grass carp (Ctenopharyngodon idela) is the major species cultivated in PRD. It is an herbivore, which stays at the upper water column and consumes grasses and other macrophytes. Digested pig manure serves as pond fertilizer, and nutrients released will result in luxurious growth of planktons, serving as food for filter feeders such as bighead (Aristichthys molitrix). Omnivorous species such as mud carp (Cirrhina molitorella) feed on various items, mainly benthic organisms (snails and worms), and tilapia (Tilapia spp) feeds on all kinds of materials, including digested pig manure and fecal matters from other fish species. Pond mud is excavated regularly and used as fertilizer for crops growing on dykes. As such, all the residual energy derived from the wastes could be fully utilized (Milstein et al, 1995). It is expected that uptake of PTS into different species of fish will depend on their growth conditions, ecological niches and their specific feeding modes. Theoretically, carnivores at higher trophic levels tend to accumulate more PTS, due to bioaccumulation and biomagnification along the food chain. Bioaccumulation and biomagnfication of $\mathrm{Hg}$ in aquatic food webs are common phenomena worldwide, including the Arctic (pelagic food web) (Ruus et al, 2015). Fortunately, due to the less complicated food webs in freshwater fish ponds, and the relatively short-period of cultivation of most freshwater fish, the effect of biomagnification of PTS is not considered serious (Cheng et al, 2013a).

These integrated agriculture-aquaculture systems were once popular during 1960-90s, with variations concerning the components of crops, including sugar cane, vegetables, and fruits. The most well-known example is "Mulberry bund-Fish Pond" agroecosystem, planted with mulberry trees, with leaves used for growing silk worms, and the cacoons (after extraction of silk) are served as feeds for fish (Wong et al, 2004). There has been a decline in the practices of these integrated systems in the region, due to reasons specified below.

\subsection{Recent Changes and Contamination of Food Products}

Being the first "Economic Zone" in the whole of China, PRD has undergone rapid socio-economic change during the past 30 years, with rapid population growth, urbanization and industrialization. Different industries were moved from Hong Kong to the region, taking advantages of cheaper raw materials and labour costs, and the less stringent environmental regulations in the mainland. The region has in fact transformed to the world's centre for manufacturing electronic/electrical 
equipment, textiles and pharmaceutical products, discharging a wide range of PTS into the Delta. The $\mathrm{Pb}$ and zinc $(\mathrm{Zn})$ mine located in Shaoguan (north of Guangdong Province) is the $2^{\text {nd }}$ largest $\mathrm{Pb} / \mathrm{Zn}$ mine in China, which discharges a high volume of effluent containing elevated levels of $\mathrm{Pb}$ and $\mathrm{Zn}$ into the vicinity, affecting crop and fish production. Recent review articles concerning environmental pollution: heavy metals, POPs, and ECCs in China all identified that the Pearl River Delta is one of the hot spots for these PTS: Hg (Zhang \& Wong, 2007), DDT (Wong et al, 2005), PBDE (Zheng et al, 2012), PCDD/Fs, bisphenol A (Huang et al, 2012), PFOS (Zhao et al, 2012a), and pharmaceutical and health care products (PPCPs) (Liu \& Wong, 2013).

The change of land use also affects our food production systems, as large areas of fertile soils and fishponds have been used for the constructions of highways and housing estates. Marginal land has been claimed for both agriculture and aquaculture which required additional inputs of fertilizers and pesticides, resulting in further deterioration of soil and water quality. Large amounts of fertilizers are used in reclaiming marginal land, or in limited farmed soils to enhance/maintain soil fertility. Unfortunately, some of the fertilizers used are contaminated (e.g. rock phosphates are known to contain elevated levels of $\mathrm{Cd}$, which explain the fact that higher $\mathrm{Cd}$ concentrations are found in farm soils and vegetables produced in a majority of farms around PRD, including those catered for Hong Kong consumers, because of the repeated use of such fertilizer (Hu et al, 2012). In addition, industrial ash, contaminated with heavy metals and POPs is being recycled as fertilizers, threatening human health risks due to consumption of contaminated crops (Chaney, 2012).

The high demand of electricity to meet various industrial developments has resulted in emissions of pollutants via coal combustion, from power stations, especially those substandard ones, which lack emission control. Toxic chemicals, such as $\mathrm{Hg}$ contained in coal will be emitted into the air, then finding its way to our food production systems (soil and water) through aerial deposition. Under anaerobic conditions, e.g. sediment in fish ponds, or beneath mariculture rafts, inorganic $\mathrm{Hg}$ may be transformed to organic $\mathrm{Hg}$ (i.e. methyl $\mathrm{Hg}$ ), via sulphide reducing bacteria, which will be efficiently taken up by fish (inland aquaculture: Shao et al, 2012; mariculture: Liang et al, 2011; 2013).

\subsection{Contamination of Fish in Local Markets}

Among all food items, it is known that fish, especially large predatory fish tend to contain higher levels of $\mathrm{Hg}$, through bioaccumulation and biomagnification in aquatic food chains. In addition, our early survey (Qin et al, 2011) on levels of POPs in some common food items, including meat, edible oils, nuts, milk and wine collected from Hong Kong. It was noted that goose liver accumulated the highest PAHs (47.9 ng/g wet wt), DDTs (25.6), HCHs (13.0), PCBs (4.17), PBDEs (468 pg/g wet wt) among all the selected food. In general, positive correlations between lipid contents and concentrations of different POPs were observed. Therefore, in order to minimize our exposure to environmental pollutants, it seems logical to avoid intake of food items which contained higher fat contents such as goose liver, fatty fish, carnivorous fish and shellfish which are known to contain 
different pollutants.

In addition to As (Cheng et al, 2013b), Hg and other heavy metals (Cheung et al, 2007a), different fish species cultivated and/or available in local markets are also polluted by POPs, e.g. DDT (Leung et al, 2010), organochlorine pesticides (Cheung et al, 2007b; Wang et al, 2011a), PAHs (Cheung et al, 2007b; Wang et al, 2011c), dioxin- and estrogenic-like pollutants (Wei et al, 2010; 2011a), PBDE (Cheung et al, 2008; Wang et al, 2011b), and ECCs such as bisphenol A (Wei et al, 2011b), phthalate esters (Cheng et al, 2013c) and PFOS (Zhao et al, 2011, 2012) in the region.

In the past, animal manure (pig and poultry manure) from nearby animal farms is used as pond fertilizer to enrich pond water, for enhancing luxurious growth of planktons. However, due to the recent outbreaks of avian flu, animal farms are now largely separated from inland fish ponds. Therefore, the traditional practice of this integrated agriculture - aquaculture farming system has been gradually declined, replacing by monoculture of high-priced fish, fed with trash fish and high protein fish pellets (consisting of a large proportion of fishmeal).

One good example of the high-priced fish species cultivated in the region is Mandarin fish or Chinese perch (Siniperca chuatsi). It is grown under high density, using trash fish as major feed ingredients, with frequent application of antibiotics to enhance fish immunity. China produces and consumes the most antibiotics among all countries in the world, with half of the antibiotics manufactured and used in the production of livestock. It has been estimated that 85.5 million $\mathrm{kg}$ of antibiotics were used in China for pig and poultry production in 2012 (Krishnasamy et al, 2015).

The global report on surveillance of antimicrobial resistance (WHO, 2014) indicated that serious threat is happening right now in every region of the world, threatening anyone, of any age, in any country. It is now a major threat to human health due to the fact that some antibiotics are no longer work in people who need them to treat infections. It has been observed that pig manure fertilizer could also pose human health risks, with higher rates of antibiotic-resistant infection (Staphylococcus aureus bacteria): methicillin-resistant (MRSA), meaning that treatment with standard antibiotics does not work (Zhang, 2013).

\subsection{Environmental Pollution and Cancer Villages}

There seem to be more or more evidence concerning the potential linkages of environmental contaminants with health problems. Common health problems such as cancers are associated with $\mathrm{As}$, asbestos and dioxins; neurological damage and lower $\mathrm{IQ}$ with $\mathrm{Pb}, \mathrm{As}$, and $\mathrm{Hg}$; kidney disease with $\mathrm{Pb}, \mathrm{Hg}$ and $\mathrm{Cd}$; and skeletal and bone diseases with $\mathrm{Pb}, \mathrm{F}$ and $\mathrm{Cd}$ are serious issues in developing countries (Bouwman et al, 2012). In reviewing environmental pollution and the global burden of disease, Briggs (2003) indicated that about $8-9 \%$ of the total disease burden may be attributed to pollution, with considerably more in developing countries, due to unsafe water, poor sanitation and poor hygiene, and indoor air pollution are the major sources of exposure. 
Death rates in communities close to chemical, pharmaceutical or power plants exceed the national average. China's environmental ministry acknowledges the existence of these so-called "cancer villages" after years of public speculation concerning the impact of pollution in certain areas, admitting that the widespread production and consumption of harmful chemicals forbidden in many developed nations are still found in China. In fact, the latest report of the environmental ministry entitled "Guard against and control risks presented by chemicals to the environment during the $12^{\text {th }}$ Five-Year period (2011-2015)" indicated that the toxic chemicals causing water and air pollution could pose a long-term risk to human health, making a direct link to the so-called "cancer villages (BBC News, 2013).

A total of 459 cancer villages have been identified across 29 of China's 31 provinces (except Tibet and Qinghai). There are also cancer villages in Guangdong Province (South China): including South (the PRD), East, West and North (mountainous) regions. Unfortunately, the situation of Shangba Village seems to be the worst among all cancer villages in China. It is located at south of the mining areas receiving the discharges of mine effluent containing high concentrations of $\mathrm{Cd}, \mathrm{Pb}$ and other toxic metals from the mines located at north of Guangdong Province. There were over 250 villagers, around 50 years of age (out of the total number of 3,329 people living in the village in 2008) died of cancer, from 1978 to 2005 in Shangba Village (Liu, 2010). The fact that the PRD has become the world's manufacturing centre for different products, and the rather wide spread of electronic waste recycling activities in the region (using primitive techniques such as baking and acid digestion of electronic boards, and opening of electronic waste) (Wong et al, 2007), all together emitted a wide range of PTS further aggravated the problem.

There has been at least an $80 \%$ increase in cancer deaths, since the start of economic reforms, 30 years ago in China. According to the 2012 report from the National Central Cancer Registry of China (data of 2009), there is about 3.12 million new cancer cases developing annually. It has been noted that lung cancer rates (about 32\%) have increased, while rates of gastric, esophageal and cervical cancer declined over the last decade (China Real Time, 2015). In Hong Kong, the top 10 most common cancers are colorectum, lung, breast, liver, prostate, stomach, non-melanoma skin, corpus uteri, non-Hodgkin lymphoma, and nasopharynx cancers for both male and female (Hong Kong Cancer Registry, 2013).

A large number of factors are believed to increase the risk of getting colorectal (bowel) cancer. There is evidence suggesting that it may be linked with the diet of high animal fat and protein, and low in fibre, although obesity, lack of exercise, smoking and alcohol may also increase the risk. People with a family history of bowel cancer may have an increased risk of developing the disease (Cancer Fund, 2015). There seems to be a severe data gap, concerning oral intake of PTS and potential health risks, in particular colorectal cancer. 
Qin et al (2010) attempted to investigate the potential linkages of environmental contaminants including POPs and heavy metals detected in adipose tissues of patients who had uterine leiomyomas. Results showed that these patients had significantly higher concentrations of DDTs, $\mathrm{HCHs}, \mathrm{PCBs}, \mathrm{PAHs}, \mathrm{PBDEs}, \mathrm{As}, \mathrm{Cd}, \mathrm{Pb}$ and $\mathrm{Hg}$ in both their visceral fat, and subcutaneous fat than those of the healthy control. These POPs and heavy metals may have correlations with uterine leiomyomas, and their accumulation in the body is positively correlated with seafood diet habit, body mass index, and age. However, more detailed study is needed before a more concrete conclusion can be drawn showing the association of environmental pollutants, body loadings and health symptoms, in this case uterine leiomyomas.

\section{MERCURY IN THE ENVIRONMENT}

This section is devoted to review the sources, and fates of $\mathrm{Hg}$ in the environment, and human exposure pathways, body loadings of $\mathrm{Hg}$, potential health effects, socio-economic impacts, policy and control. It is hoped that this review could serve as valuable reference for other less known PTS, which share similar characteristics as $\mathrm{Hg}$.

\subsection{Sources and Fates of $\mathrm{Hg}$ in the Environment}

The global concerns with regards to $\mathrm{Hg}$ can be summarized as follows: 1 ). It is predominately generated by coal combustion from coal power plant stations throughout the world, which is increasing worldwide, especially in Asia; 2). It is transported from these sources in the air, and deposited on land and water surface; and 3). It is transferred to humans through consumption of fish, through international or socioeconomic boundaries (Chen, 2011).

It is recognized Asia is the largest contributor of anthropogenic atmospheric $\mathrm{Hg}$, consisted of more than $50 \%$ of global emissions (Wong et al, 2006). China topped the 10 largest global emitters of $\mathrm{Hg}$ in the world, with $604.7 \mathrm{t}$, contributing about $28 \%$ to the global emissions, followed by South Africa with $256.7 \mathrm{t}$, and India with $149.9 \mathrm{t}$ (Pacyna et al, 2006). Within China, the total anthropogenic sources of $969 \mathrm{t}$ (based on data of 2003) comprised of nonferrous metal smelting (321 t), coal combustion ( $257 \mathrm{t}$ ) and cement production (35 t) (Wu et al, 2006), emitting $\mathrm{Hg}$ into the atmosphere.

Table 1: Ten largest global emitters of $\mathbf{H g}$ (Pacyna et al, 2006)

\begin{tabular}{|l|l|l|}
\hline Number & Country & Total $(\mathrm{t})$ \\
\hline 1 & China & 604.7 \\
\hline 2 & South Africa & 256.7 \\
\hline 3 & India & 149.9 \\
\hline 4 & Japan & 143.5 \\
\hline 5 & Australia & 123.5 \\
\hline 6 & USA & 109.2 \\
\hline
\end{tabular}




\begin{tabular}{|l|l|l|}
\hline 7 & Russia & 72.6 \\
\hline 8 & Kazakhstan & 43.9 \\
\hline 9 & Korea Democratic Republic & 46.0 \\
\hline 10 & Saudi Arabia & 40.7 \\
\hline & TOAL & 1590.7 \\
\hline
\end{tabular}

Mercury comes from both natural and anthropogenic sources (Mason, 2009), and the amount of $\mathrm{Hg}$ entering into the environment has increased by 2-5 $\mathrm{x}$ since the Industrial Revolution. There is a worldwide increase in the atmospheric deposition of $\mathrm{Hg}$ in densely populated and industrialized areas (Lamborg et al, 2002).

Characterization of $\mathrm{Hg}$ emissions and their behavior were conducted in six typical coal-fired power plants in China. It was observed that the total $\mathrm{Hg}$ concentrations in the flue gas from boilers (ranging from 1.92 to $27.15 \mu \mathrm{g} / \mathrm{m3}$ ), were significantly related to the $\mathrm{Hg}$ contents in burned coal. Efforts have been made to reduce $\mathrm{Hg}$ emissions from coal combustion in power plants, based on the process optimization guidance: $\mathrm{Hg}$ emission reduction practices, which included energy efficiency improvement measures, pre-combustion control measures (e.g., coal blending, coal cleaning), etc., to maximize $\mathrm{Hg}$ removal (UNEP, 2010).

\subsection{Biogeochemical cycle, Methylation, Bioaccumulation and Biomagnification}

Basically $\mathrm{Hg}$ is a natural element which occurs in terrestrial and aquatic ecosystems. There are several forms of $\mathrm{Hg}$ in the environment: it is predominantly elemental $\mathrm{Hg}(\mathrm{HgO})$ in the atmosphere, inorganic form ( $\mathrm{Hg} 2+)$ in water, and it is transformed to organic form (MeHg). The biogeochemical cycle has six major steps (Pirrone et al, 1996): 1) Degassing of Hg from rock, soils, and surface waters, or emissions form volcanoes and from anthropogenic activities; 2) Movement in gaseous form through the atmosphere; 3) Deposition of $\mathrm{Hg}$ on land surface waters; 4) Conversion of the elemental $\mathrm{Hg}$ into insoluble mercury sulfide; 5) precipitation or bioconversion into more volatile or soluble forms such as $\mathrm{MeHg}$; and 6) Either re-entry into the atmosphere or bioaccumulation in food chains.

It is commonly observed that under anaerobic environment, sulfide reducing bacteria are able to transform inorganic $\mathrm{Hg}$ to organic $\mathrm{Hg}$. Being the most toxic organic form, MeHg is efficiently bound to adipose tissues of living organisms. Through bioaccumulation and biomagnification along food webs and food chains, $\mathrm{Hg}$ and other PTS such as DDT, will be concentrated in higher trophic organisms (Zhou \& Wong, 2000), and in fact, trophic position of fish generally determines uptake of contaminants, with carnivorous fish accumulating more than herbivorous fish (Cheng et al, 2013a).

The elevated $\mathrm{Hg}$ levels found in predatory fish have posed subsequent risks to populations of piscivorous (fish eating) predators such as osprey, eagles, herons, kingfishers, and songbirds, 
thriving in methylating environments such as wetlands, streams, lakes, etc., resulting in reduced reproductive success (Depew et al, 2013). For example, it was noted that the reproductive success of the Carolina bird (Thryothorus ludovicianus) was associated with MeHg exposure in those birds nesting along forest floodplains of contaminated rivers (Jackson et al, 2011). In a study dosing dietary MeHg (0.3-2.4 ppm) in a model songbird species, the zebra finch (Taenniopygia guttata), the results showed that all doses reduced reproductive success, with the lowest dose reducing the number of independent offspring produced in one year by $16 \%$, and the highest dose, resulting in a 50\% reduction (Varian-Ramos et al, 2014). Adverse effects of $\mathrm{Hg}$ exposure in reptiles and mammals are also frequently reported (Schneider et al, 2013).

More recently, there seems to be more and more evidence showing potential adverse health effects due to long-term exposure of $\mathrm{Hg}$ associated with consumption of contaminated fish. There are warnings by many public health agencies about pregnant women and children, limiting their consumption of predatory fish (tuna, swordfish, and sharks), e.g. US Food and Drug Administration/US Environmental Protection Department (USFDA/USEPA, 2004), and Centre for Food Safety, Hong Kong (CFS, 2008). Nevertheless, the ecological dimensions and potential health effects of $\mathrm{Hg}$ seem to be far more subtle than either the Minamata tragedy or the health warnings suggested.

Based on an "ecosystem approach", Lebel (2003) revealed how deforestation and farming practices in the Amazon caused subclinical and yet debilitating neurological manifestations. For studies related to "Eco-Health", a fuller picture could be obtained upon using a transdisciplinary approach that spans a wide range of disciplines, from biogeochemistry and ecosystem ecology to epidemiology and participatory action, with regards to environmental exposure to $\mathrm{MeHg}$ (Chen, 2011).

\subsection{Methylation of $\mathrm{Hg}$ in the Natural and Aquaculture Environment}

An attempt was made to investigate $\mathrm{Hg}$ trends in fish from rivers and lakes in the US, based on the national dataset compiled mainly from state and federal monitoring programs between 1969 and 2005, and it was noted that in general $\mathrm{Hg}$ concentrations in fish will respond to changes in atmospheric $\mathrm{Hg}$ deposition, but the magnitude and timing of the response is not certain. However, the most downward trends in fish $\mathrm{Hg}$ concentrations in both fish and sediment cores were consistent with the implementation of stricter regulatory control of releasing $\mathrm{Hg}$ (to air and surface waters) during 1970s and 1980s (Chalmers et al, 2011).

The METALLICUS (2010) project is aimed at assessing atmospheric loadings of $\mathrm{Hg}$ in Canada and the US, to answer "whether a reduction in atmospheric $\mathrm{Hg}$ emissions will reduce $\mathrm{Hg}$ concentrations in fish". It is based on the whole ecosystem Hg loading study (carried out in the Experimental Lakes Area of Ontario, Canada) to test the watershed-scale response to a change in $\mathrm{Hg}$ load. The major purpose is to answer whether the policy (proposed regulations) would result in 
the intended benefit: the controls on industrial emissions of $\mathrm{Hg}$ will cost billions of dollars per year if implemented. The project consisted of three phases: 1) pre-dosing (or baseline studies), 1999-2000; 2) loading phase, 2001-2007 (adding stable, non-radioactive isotopes of inorganic $\mathrm{Hg}$ $(\mathrm{Hg}+2)$, and 3) recovery phase, 2008 onwards.

Orihel et al (2007) showed the experimental evidence of a linear relationship between inorganic $\mathrm{Hg}$ loading and MeHg accumulation by aquatic biota; while Paterson et al (2006) indicated bioaccumulation of newly-deposited $\mathrm{Hg}$ by fish and invertebrate, based on an enclosure study using stable $\mathrm{Hg}$ isotopes. Another study noted that $\mathrm{Hg}$ levels in fish have increased in the Everglades National Park (Florida) more recently; with $60 \%$ of the Everglades marsh area had sulfate concentrations greater than historical levels, which would promote $\mathrm{Hg}$ methylation (Axelrad et al, 2007a). Harris et al (2007) further showed that there was a preferential bioaccumulation of isotope $\mathrm{MeHg}$ in the food chain, and rapid fish-Hg response to changes in $\mathrm{Hg}$ deposition. It was revealed that the newly added $\mathrm{Hg}$ to the surface of the lake was methylated a lot more efficiently than the total amount of $\mathrm{Hg}$ existed in the ecosystem. The newly deposited $\mathrm{Hg}$ contributed substantially to MeHg production and bioaccumulation within aquatic systems. Therefore, it is envisaged that rapid reductions in $\mathrm{Hg}$ emissions should result in rapid benefits to human and wildlife health (Benoit et al, 2001).

The coal-fired power plants scattered in South China are major sources of $\mathrm{Hg}$ found in different environmental compartments. Accumulation of unconsumed feeds (very often trash fish for feeding carnivorous fish in PRD) and fecal matter from the cultured fish in the sediment of freshwater fish ponds and beneath the mariculture rafts may create an anaerobic conditions for the sulfide reducing bacteria to transform inorganic $\mathrm{Hg}$ to organic $\mathrm{Hg}$ (i.e. MeHg) (Liang et al, 2011; 2013a; Shao et al, 2012).

\section{Potential Health Risks of Consumption of Contaminated Fish, Focusing on $\mathrm{Hg}$}

\subsection{Minmata Disease - Acute Poisoning}

Contamination of fish by heavy metals all over the world has been frequently reported. Regular consumption of fish and other seafood laden with high concentrations of mercury $(\mathrm{Hg})$ of the fishermen and families in Minamata Bay, Japan was in fact a classical case of $\mathrm{Hg}$ poisoning. It was caused by the release of inorganic $\mathrm{Hg}$ ) from the Chisso Corporation's chemical factory (manufacturing acetylene, acetaldehyde, vinyl and octanol) from 1931 to 1968, and its subsequent methylation to $\mathrm{MeHg}$, and then bioaccumulation in fish and shellfish. Being a neurotoxin, MeHg attacks our central nervous system, leading to peripheral vision impairment, loss of coordination, muscle weakness; and in extreme cases, insanity, paralysis, coma and death. Fetal brain is especially vulnerable, and can be affected through placental transfer (during pregnancy) and lactation, causing developmental impairments such as reduced ability in thinking, attention span, memory, and most motor skills (Ui, 1992). 
The maximum $\mathrm{Hg}$ level recorded in patents suffered from $\mathrm{Hg}$ poisoning was 705 ppm, compared with 191 ppm of the residents, and 4 ppm for people living outside the Minamata area (Harada, 1972). The Food and Drug Administration of the USA (USFDA, 2001) has an action level for MeHg in both commercial marine and freshwater fish of $1 \mathrm{ppm}$, and in Canada the limit for total $\mathrm{Hg}$ content is $0.5 \mathrm{ppm}$. It has been recommended that women who are pregnant or plan to become pregnant within the next one or two years, and also young children should avoid eating more than 6 ounces (one average meal) of fish (especially large predatory fish such as tuna, sword fish and shark, with extremely high concentrations of $\mathrm{Hg}$ in fish tissues, due to biomagnification of $\mathrm{Hg}$ along aquatic food chains), in a week.

\subsection{Long-term Effects of Low Dosage Intake}

In Hong Kong, by analyzing 266 whole fish and 14 canned fish, a survey conducted by the Centre for Food Safety, Hong Kong (CFS, 2008) shows that total Hg and MeHg concentrations ranged from 3 to $1370 \mu \mathrm{g} / \mathrm{kg}$ (median 63) and 3 to $1010 \mu \mathrm{g} / \mathrm{kg}$ (median 48) respectively in the samples. It was noted that the dietary exposure to MeHg of secondary students below the Provincial Tolerable Weekly Intake (PTWI) for the average consumer (31-41\% of PTWI), but the high consumer $\left(95^{\text {th }}\right.$ percentile exposure level) may exceed the PTWI (94-106\% of PTWI). Pregnant women, women planning pregnancy and young children were also advised to avoid eating large predatory fish and certain species such as shark, swordfish, marlin, alfonsino and tuna.

Another early study analyzing $\mathrm{As}, \mathrm{Hg}, \mathrm{Cd}$, and $\mathrm{Pb}$ concentrations in some common marine and freshwater fish available in Hong Kong markets, and the results showed that consumption of the 10 common marine fish and 10 common marine fish species posed health risks based on total $\mathrm{Hg}$ contained in fish, with the hazard quotient (HQ) of 4.30, and 7.10 respectively, while $\mathrm{As}, \mathrm{Cd}$ and $\mathrm{Pb}$ did not seem to pose any problem (with HQ all lower than 1) (USEPA, 2009). In fact, a study in Taichung (middle of Taiwan) examined 14 commonly consumed seafood items, and found that mean total $\mathrm{Hg}$ varied nearly 100 -fold across species, with $50 \%$ of the marlins sampled and $35 \%$ of the sharks exceeded the $0.3 \mu \mathrm{g} / \mathrm{g}$ US EPA guideline (Fang et al, 2011). In fact, shark fins, a symbol of good fortune and wealth, commonly consumed among Chinese communities contained very high levels of $\mathrm{Hg}$ (Man et al, 2014).

Table 2 Daily intakes of MeHg through fish consumption, based on 10 common freshwater and 10 common marine fish species available in local markets in Hong Kong (Cheung et al, 2007a)

\begin{tabular}{|l|l|l|l|l|l|l|}
\hline Fish & $\begin{array}{l}\text { Ave conc } \\
\mu \mathrm{g} / \mathrm{g} w \mathrm{ww}\end{array}$ & $\begin{array}{l}\mathrm{EDI} \\
\mu \mathrm{g} / \mathrm{kg} \mathrm{bw} / \mathrm{d}\end{array}$ & $\begin{array}{l}\text { ADI\# } \\
\mu \mathrm{g} / \mathrm{kg} / \mathrm{bw} / \mathrm{d}\end{array}$ & $\begin{array}{l}\text { Ratio of } \\
\text { EDI to ADI }\end{array}$ & $\begin{array}{l}\text { RfD\$ } \\
\mu \mathrm{g} / \mathrm{kg} / \mathrm{bw} / \mathrm{d}\end{array}$ & $\begin{array}{l}\text { Hazard } \\
\text { quotient }\end{array}$ \\
\hline Freshwater fish & & & & & & \\
As (inorganic) & $0.09 *$ & 0.23 & 2.15 & 10.7 & 0.3 & 0.07 \\
$\mathrm{Cd}$ & 0.10 & 0.25 & 1.00 & 25.5 & 1.0 & 0.25 \\
$\mathrm{~Pb}$ & 0.26 & 0.66 & 3.60 & 18.4 & & \\
$\mathrm{Hg}$ (total) & 0.17 & 0.43 & 0.71 & 61.0 & $0.1 @$ & 4.30 \\
\hline
\end{tabular}




\begin{tabular}{|l|l|l|l|l|l|l|}
\hline Marine fish & & & & & & \\
As (in organic) & 0.26 & 0.66 & 2.15 & 30.8 & 0.3 & 0.27 \\
$\mathrm{Cd}$ & 0.05 & 0.13 & 1.00 & 12.8 & 1.0 & 0.13 \\
$\mathrm{~Pb}$ & 0.15 & 0.38 & 3.60 & 10.6 & & \\
$\mathrm{Hg}$ (total) & 0.28 & 0.71 & 0.71 & 100 & 0.1 & 7.10 \\
\hline
\end{tabular}

EDI: Estimated daily intake $=$ Ave conc $(\mu \mathrm{g} / \mathrm{g}) \times$ consumption $(142.4 \mathrm{~g} /$ day $) /$ body weight $(55.9 \mathrm{~kg})$. Hazard quotient $=E D I / R f D$. If the ratio is less than, there will be no obvious risk.

*Ave conc of inorganic As was estimated by using a value of $10 \%$ of total As (USFDA, 1993).

\# Calculated from PTWI set by JECFA (1993).

\$ Reference dose of metals established by USEPA (2005).

@ Methyl Hg accounts for > 95\% of total Hg in fish (Bloom, 1992).

A more recent study based on the evaluation of $\mathrm{THg}$ and MeHg exposure of Hong Kong residents, via consumption of freshwater and marine fish, it was noted that that concentrations of $\mathrm{THg}$ $(64.4 \pm 28.5 \mathrm{ng} / \mathrm{g})$ in marine fish were significantly greater than those in freshwater fish $(40.3 \pm 26.0$ $\mathrm{ng} / \mathrm{g}$ ). Based on the total concentrations, diets of $36 \%$ of adults and $51 \%$ of children exceeded the reference dose (RfD) of $100 \mathrm{ng} / \mathrm{kg} / \mathrm{body}$ mass/day) for $\mathrm{MeHg}$, although when bioaccessibility (based on in vitro gastrointestinal assay) was considered, consumption of these fish resulted in $9 \%$ of children had an EDI exceeded the RfD of MeHg, while adults were not affected (Wang et al, 2013).

Our subsequent study evaluating the sources and fates of $\mathrm{Hg}$ in the aquaculture and mariculture systems of the PRD noted that in addition to environmental pollution, the trash fish and also fish feed pellets containing larger portions of fish meal (usually made from trash fish) popular for feeding carnivorous fish, were contaminated by Hg. Furthermore, the unconsumed feeds and fecal matter generated from the cultured fish accumulated in pond mud (freshwater fish culture), and sediment beneath mariculture rafts (marine fish culture), provided an anaerobic environment, with sulfide reduction bacteria efficiently transforming the inorganic $\mathrm{Hg}$ to organic $\mathrm{Hg}$ (i.e. $\mathrm{MeHg}$ ) (Liang et al, 2011, 2013a; Shao et al 2012). This may lead to higher uptake of Hg by the cultured fish and also the nearby wild fish, but further research is needed before a more concrete conclusion can be drawn. Fortunately, the duration of fish culture is usually short, from several months to one or two years, and the rather short food chains within freshwater fish ponds prohibit biomagnification of $\mathrm{Hg}$ in freshwater fish (Cheng et al, 2013a).

A subsequent study investigating the potential health risks associated with dietary consumption of $\mathrm{Hg}$ around the PRD, hair samples (from 91 urban, town and fishing village residents), and food items (37 species of fish, cereal, vegetables and meat samples) were collected and analyzed. The average $\mathrm{THg}$ and $\mathrm{MeHg}$ concentrations in hair of 1.08 and $0.58 \mu \mathrm{g} / \mathrm{g}$, respectively were significantly correlated with the daily $\mathrm{Hg}$ intake via fish consumption (Shao et al, 2012). An attempt has also been made using human blood (plasma) of Hong Kong residents as an indicator for the evaluation 
of human exposure to $\mathrm{Hg}$. Results indicated that the mean values of $\mathrm{THg}$ and $\mathrm{MeHg}$ concentrations were 0.62 and $0.28 \mu \mathrm{g} / \mathrm{L}$ respectively, which were also significantly correlated with the fish consumption rates of hair donors (Liang et al, 2013b).

\subsection{Hg Overload and Effects on Human Health}

\subsubsection{Human reproduction}

Regular intake of fish contaminated with relatively low concentrations of $\mathrm{Hg}$ and other heavy metal/loids, such as $\mathrm{As}, \mathrm{Cd}$ and $\mathrm{Pb}$ has become a more recent public health concern. Dr. Milton $\mathrm{KH}$ Leong and Dr. Clement KM Leung, the two medical doctors delivered the first test tube baby in Hong Kong back in 1986. Throughout the past 30 years, they have accumulated substantial information on the causes of sub-fertility in Hong Kong males, with abnormal semen parameters, including semen volume lower than $2 \mathrm{ml}$, sperm count lower than 20 million/ml, sperm motility smaller than 50\% and normal sperm morphology smaller than 50\% (WHO, 1999). In fact, spermatogenesis provides a unique biological window to examine human response to environmental insults, at cellular levels.

Attempts were then made to search for any association between the above parameters (and other clinical data including testicular volume and scrotal varices) of 117 patients (sub-fertile males, between age 25-72), with a number of personal data and lifestyle, such as age, height, weight, tobacco consumption (number of cigarette/day), hot tub-bath, fish consumption (fish meals/week), mineral water consumption (number of bottles/week), number of amalgam tooth fillings, intake of Chinese herbs, duration of residence (year), and district of residence in Hong Kong. Results showed that the hair $\mathrm{Hg}$ content of these sub-fertile males with tooth amalgam (4.74 ppm, compared with those without $3.73 \mathrm{ppm}$ ) was higher than those without ( $27 \%$ higher), but the results were not significant. However, hair $\mathrm{Hg}$ increased significantly with the increase in fish intake (30\% higher). Those with more than 4 times/week fish meal contained 5.05 hair $\mathrm{Hg}$ compared to those with less than 4 times/week of 3.86 ppm (Dickman \& Leung, 1988; Dickmen et al, 1988).

\subsubsection{Autism}

Based on the analyses of 1057 cord blood samples in Hong Kong, it was noted that $78.4 \% \mathrm{had} \mathrm{Hg}$ concentrations higher than $5.8 \mathrm{\mu g} / \mathrm{L}$. Increasing maternal fish (especially marine fish) consumption was associated with increased cord blood $\mathrm{Hg}$ (Fok et al, 2007). In a study conducted in Spain (Valencia), Ramon et al (2009) revealed that $75 \%$ cord blood samples had $\mathrm{Hg}$ concentrations above $5.8 \mu \mathrm{g} / \mathrm{L}$. Women consumed fish 2 or more times/week resulted in mean cord blood levels of 1.6, 1.4, and 1,3 times higher than those who rarely or never eat fish. The study conducted in Turkey (Istanbul) observed that fish consumption more than twice/week, and tooth-filling of mother more than 5 may increase $\mathrm{Hg}$ level in blood (Unuvar et al, 2008).

Autism appears during infancy or childhood, is a highly variable neurodevelopmental disorder. There has been a long debate concerning the causes of autism, with "Genetic factors" considered 
the major causes among the mainstream autism scientists. Although quite a few rare genetic disorders and toxic exposures are known to cause autism, most cases of autism are considered "idiopathic" (meaning without known cause). It has been suggested that Mumps-Measles-Rubella (MMR) vaccine may cause intestinal problems leading to the development of autism; and that "thimerosal" a Hg-based (containing $\mathrm{MeHg}$ ) preservative used in some vaccines, may be connected to autism (Pinel, 2011).

Nevertheless, "environmental factors" have received more and more attention recently. These included certain foods, infectious disease, heavy metals, solvents, diesel exhaust, PCBs, phthalates and phenols used in plastic products, pesticides, brominate flame retardants, alcohol, smoking, illicit drugs, and vaccines (Newschaffer et al, 2007). Epigenetic changes will occur due to DNA sequence changes, and chromosmal histone modification or modification of the DNA bases, which are known to be affected by environmental factors (Miyake et al, 2012).

Among all toxic metals, both $\mathrm{Pb}$ and $\mathrm{Hg}$ are neuro toxins, which are suspected to contribute to development of autism in children, as the blood and hair levels of autistic children are significantly higher than typical (Pb: Zafeiriou et al, 2007; Hg: Austin, 2008). However, there is no direct association between autism and postnatal exposure to any neurotoxicant (Davidson et al, 2004). Due to the fact that the primary source of organic $\mathrm{Hg}$ exposure in humans is MeHg exposure from fish consumption, and studies have been conducted on the potential linkage on $\mathrm{Hg}$ exposure through fish consumption.

Ko et al (2012) examined the data generated from analyses of $\mathrm{As}, \mathrm{Cd}, \mathrm{Hg}$ and $\mathrm{Pb}$ in hair samples of autistic children from different parts of China. Results revealed that autistic children from coastal areas (e.g. Hong Kong, Guangdong, Shanghai and Fujian) had significantly higher concentrations of $\mathrm{Hg}$ and $\mathrm{Cd}$, while those from inland areas (e.g. Beijing, Hubei, Hunan and Jiangsu) significantly higher $\mathrm{As}$ and $\mathrm{Pb}$. This was possibly due to the fact that coastal residents had a higher consumption rate of seafood, such as fish and shellfish (higher $\mathrm{Hg}$ in fish and $\mathrm{Cd}$ in shellfish); and inland residents exposed to more serious environmental pollution (higher As in drinking water, $\mathrm{Pb}$ in paint and dust). The above studies all showed that dietary preference, and major environmental pollutants (soil, water and air pollution) from different regions of China, tend to determine the major exposure pathways of contaminants.

\subsection{Effects of Prenatal Exposure and Socio-economic Effects}

Through the analyses of mental (MDI) and psychomotor developmental index (PDI) of 474 children in Poland (Krakow), it was noted that $\mathrm{Hg}$ cord blood level above $0.9 \mu \mathrm{g} / \mathrm{L}$ is associated with delayed neurocognitive \& psychomotor status of children at 12 months of age (prenatal exposure) (Jedrychowski et al, 2007). Wijngaarden et al (2013) attempted to study autism spectrum disorder (ASD) phenotypes (Social Responsiveness Scale) and prenatal exposure (maternal hair) to MeHg, in Seychelles, where fish consumption is high. Results showed that prenatal exposure to MeHg was 
not associated with ASD phenotypic behaviors in the cohort of high fish consumers. Davidson et al (2010) conducted a study on fish consumption, $\mathrm{Hg}$ exposure and their associations with scholastic achievement in child development, also in Seychelles, and noted that prenatal MeHg exposure at dosages achieved by mothers consuming a diet high in fish are not significantly correlated with adverse educational measures of scholastic achievement. However, there were significant adverse associations between examination scores and postnatal exposure for males.

There have been concerns on prenatal $\mathrm{Hg}$ exposure will affect childhood development, with adverse effects such as attention deficits, IQ, motor, memory, language impairment. Axelrad et al (2007b) examined the IQ data from 3 longitudinal studies conducted in Faroe Islands, the Seychelles Islands, and New Zealand, and noted that childhood IQ decrease of 0.18 points per ppm rise in maternal hair $\mathrm{Hg}$, with fish consumption the most common route of human exposure to MeHg. IQ is a well-established endpoint commonly used in cost-benefit and economic analyses of the effects of environmental contaminants.

There is a substantial number of studies attempting to measure environmental and social costs due to Hg exposure. There are two general approaches to quantify benefits to human health associated with reduced $\mathrm{Hg}$ exposure: 1). Benefit-cost analysis (BCA) - which evaluates changes in health using monetary values. The economic efficiency due to exposure of pregnant woman which affects the IQ of offspring, linking to future income and supplemental educational costs could be evaluated. The data of cost of illness including treatment costs, and foregone income are used. 2). Cost-effectiveness analysis (CEA) - which uses summary measures of population health, i.e. disability-adjusted life years (DALY) and quality-adjusted life years (QALY), rather than using monetary basis. It evaluates potential policies by comparing ratio of a policy's cost to its health outcome in cost per DALY (Swain et al, 2007).

There seems to be increasing evidence of linkages between exposure to environmental pollutants and development of childhood disease. Based on the dose-response relationship between prenatal exposure to $\mathrm{MeHg}$ (0.465 IQ point reduction per ppm rise in hair-Hg concentration) and neurodevelopmental consequences in terms of IQ reduction (Euro 17,363 per IQ point decrement, based on 2008), it is possible to evaluate the economic consequences of MeHg exposures. Based on the data on hair-Hg concentrations in French women of childbearing age (18-45 years) from a national sample of 126 women and from two studies conducted in coastal regions, results showed that because of higher exposure levels to $\mathrm{Hg}$ of women in coastal communities, the annual economic impacts based on these data were greater than those using the national data (Pichery et al, 2012). Based on the cost-of-illness approach to estimate health care systems costs, and used environmentally attributable fraction modeling to estimate the proportion of childhood disease due to environmental exposures, it was concluded that childhood chemical exposures (MeHg exposure, $\mathrm{Pb}$ exposure, developmental disabilities, asthma and cancer) present a significantly economic burden to European Communities (Bartlett \& Trasande, 2013). 
These indicated that efforts to reduce $\mathrm{MeHg}$ exposures would result in high social benefits by avoiding the serious and lifelong consequences of neurodevelopmental deficits in children. Benefits may be underestimated because costs linked to all aspects of neurotoxicity and to cardiovascular disease are not considered in these studies. Nevertheless, based on results generated in these studies, there seems to be an urgent need to initiate precautionary measures to minimize exposure to this hazardous pollutant.

\section{PLICTICS, CONTROL AND MANAGEMENT}

\subsection{Politics of $\mathrm{Hg}$ Issue}

For the general public, the main concern is the potential adverse effects of exposure to $\mathrm{Hg}$ through fish consumption, and the receipt of dental amalgams and thimerosal, a preservative commonly used in vaccines. However, there are politics behind this issue in the past. The mercury study report to Congress submitted by USEPA (1997) indicated that "Mercury methylation and subsequent uptake in fish is complex and not well understood. As a result, it cannot be assumed that a change in total mercury emissions will be linearly related to any resulting change in methylmercury in fish, nor over what time period these changes would occur." It was concluded that "On the basis of these scientific facts, EPA has no "appropriate and necessary" justification for a rulemaking to limit mercury emissions from US power plants". Furthermore, in a review article related to $\mathrm{Hg}$ toxicology, Clarkson et al (2003) reassured the medical profession that there is no relation of health risk from low dose $\mathrm{Hg}$ exposure, based on current exposures and clinical manifestations. There have been vested financial interests in various sectors, including manufacturers of "Thimerosal vaccines" containing ethylmercury, coal-fired power plants, and fish industry.

"Thimerosal", a preservative used in vaccines, may link with autism (as ethylmercury constitutes $49 \%$ of thimerosal). It was based on the potential link between the levels of $\mathrm{Hg}$ exposure a person receives during early development, which may develop into autism spectrum disorder (ASD). Theoretically, when $\mathrm{Hg}$ enters human body, it binds to sulfhydryl groups on enzymes and other proteins. Upon entering into the brain and spinal cord, it affects the uptake of dopamine, serotonin, acetylcholine and norepinephrine. Eventually, it will lead to the lack of motor coordination and difficulty with communication, which is commonly observed in autistic patients (Baker, 2008). The linkage of thiomersal with autism or other neurodevelopmental disorder has become controversial, and has been rejected by major scientific and medical bodies, and also government authorities including the Food and Drug Administration (USFDA, 2008) and the Center for Disease Control (USCDC, 2008) in the USA. Nevertheless, there seems to be more concrete evidence showing associations between emissions from coal-fired power plants, fish contamination and body loadings of $\mathrm{Hg}$.

\subsection{Management and Control}


Hylander \& Goodsite (2006) indicated that the point pollution sources of $\mathrm{Hg}$ globally and their remediation costs ranged from US\$2500 to 1.1 million/ $\mathrm{kg} \mathrm{Hg}$ isolated from the biosphere, and regulations discontinuing $\mathrm{Hg}$ uses, together with extensive flue gas cleaning for all power plants and waste incinerators would be cost effective.

There are some successful policies controlling $\mathrm{Hg}$ emissions. Besides the strong positive impacts on the reduction of $\mathrm{Hg}$ bioaccumulated by fish, according to the on-going METAALICUS project mentioned above, a significant reduction in $\mathrm{Hg}$ content in fish, in South Florida was observed after major reduction in $\mathrm{Hg}$ emissions, due to new EPA emission standards (Orihel et al, 2006; Paterson et al, 2007). The control of $\mathrm{Hg}$ emissions from coal-fired power plants in US (Srivastava et al, 2006) and Canada (CCME, 2006) also achieved similar results.

A substantial number of local, state, national and international authorities have recognized $\mathrm{Hg}$ as a toxic pollutant of special concern (e.g. JECFA, 2000; NAS, 2000). In fact, fish consumption advisories for freshwater and marine fish around the US and Europe (e.g. USFDA; Schober et al, 2003), and other regions, such as Hong Kong (CFS, 2008), have been adopted. Nevertheless, an efficient global control of $\mathrm{Hg}$ is needed, and there has been a long-term effort in controlling anthropogenic emissions of $\mathrm{Hg}$ in the past. This is due to the fact that the deposition rate of $\mathrm{Hg}$ has increased by 1.5 to 3 times via increased anthropogenic emissions of $\mathrm{Hg}$ from industrial, agricultural, medicinal and domestic uses, according to the global $\mathrm{Hg}$ assessment conducted by UNEP (2013).

The Global Mercury Partnership (UNEP: Feb 2005) was established, with various programs conducted in different countries: e.g. Hg air transport \& fate research (Italy), $\mathrm{Hg}$ waste management (Japan), Hg in products (USA). Subsequently, the Global Mercury Treaty (UNEP: Feb 2009) meeting was held in Nairboi, Kenya, USA with 140 countries agreed to begin negotiations on a legally-binding instrument of the global control of $\mathrm{Hg}$ pollution.

The Intergovernmental Negotiating Committee (INC) established was aimed at: (1) reducing $\mathrm{Hg}$ emissions to the air, (2) reducing $\mathrm{Hg}$ use in products, industrial processes, and small-scale mining, (3) Hg supply, storage, and waste management, and (4) delivering technical assistance and finance. Negotiations began in 2010 and completed in 2013. During the period, attempts have been made by the UNEP in reducing risks from $\mathrm{Hg}$, by gathering more information, in particular, to see whether $\mathrm{Hg}$ contained in products is dangerous for public health. This has led to the ban of products containing $\mathrm{Hg}$, e.g., thiomerosal used in extending the shelf life of vaccines against diseases (flu, tetanus, hepatitis B, etc.) (INC, 2014).

The Minamata Convention on Mercury, was signed by delegates from 140 countries on 19 Jan 2016. This Convention is aimed at protecting human health and the environment from human activities and releases of $\mathrm{Hg}$ and its compounds. It is hoped that this international treaty will enhance the 
reduction of $\mathrm{Hg}$ pollution from targeted activities which responsible for major releases of $\mathrm{Hg}$ to the immediate environment in the future (Bailey, 2013).

\subsection{Establishment of A Regional List of PTS for Better Control}

The Hong Kong Environmental Protection Department commissioned a consultancy company: CH2M (China) Ltd (2003) to conduct "A study of toxic substances pollution in Hong Kong. It was intended to identify chemicals o potential environmental concern and develop a Priority Toxic Substances List (PTSL), based on a series of key tasks: Key Task 1: Toxic Substances of Potential Concern to Hong Kong; Key Task 2: Toxic Substance Pollution Stage of Hong Kong; Key Task 3: Ecological and Incremental Human Health Risk Assessments.

Assessments were subsequently made, which included: Water Column Organisms Risk Assessment, Benthic Organisms Risk Assessment, Marine Mammals Risk Assessment, and Incremental Human Health Risk Assessment. The results indicated that most of the ecological risk potential was to benthic communities, posed by metals found in the sediment at a limited number of "hot spots", e.g., silver, copper, and beryllium, and only zinc showed potential risk to water column organisms after the Tier 2 PRA at hot spots in north-western waters. The marine mammal risks assessment identified methyl mercury and selenium as COPC. The hazard Quotations calculated for non-carcinogenic risk of the incremental human health risk assessment for all draft PTSL chemicals were all below 1 . However, 3 chemicals: arsenic, DDD and DDE, had estimated excess lifetime cancer risk greater than the 1 in 10-6 criterion.

The major purpose of the toxic substances monitoring program initiated in 2004 (2004-2006) by The Hong Kong Environmental Protection Department (HKEPD, 2016), is to monitor and assess the extent of toxic substances pollution in the marine environment around Hong Kong.

Table 3 The PTS covered in the monitoring 2004-2006 (HKEPD, 2016).

\begin{tabular}{|l|l|}
\hline Group & Specific chemicals \\
\hline POPS & $\begin{array}{l}1^{\text {st }} \text { phase: Dioxins/Furans (PCDD/PCDF), Polychlorinated biphenyls (PCBs) } \\
2^{\text {nd }} \text { phase: Aldrin, Chlordane, Dieldrin, Endrin, Heptachlor, } \\
\text { Hexachlorobenzene, Mirex and Toxaphene }\end{array}$ \\
\hline Pesticides & $\begin{array}{l}\text { Dichlorodiphenyltrichloroethane and its metabolites (DDTs), } \\
\text { Hexachlorocyclohexanes (HCHs) }\end{array}$ \\
\hline Antifoulant & Tributylin and its metabolites (TBTs) \\
\hline Organic pollutants & $\begin{array}{l}\text { Polyaromatic hydrocarbons (PAHs), Phenol, Nonylphenol, Nonylphenol } \\
\text { ethoxylates, Polybrominated diphenyl ethers (PBDEs), Methyl Mercury } \\
\text { (MeHg) }\end{array}$ \\
\hline Non-metallic & Fluoride \\
\hline Metals & $\begin{array}{l}\text { Arsenic (total and inorganic) (As), Barium (Ba), Beryllium (Be), Cadmium } \\
\text { (Cd), Copper (Cu), Mercury (Hg), Selenium (Se), Silver (Ag), Thallium }\end{array}$ \\
\hline
\end{tabular}


The results obtained from this 2004-2006 monitoring program serve as a baseline for establishing and refining the long-term monitoring program, in particular the methodology. For the second phase, which started in 2007, other eight remaining POPs chemicals were included.

Nevertheless, there seems to be data gap concerning EECs (e.g. such as bisphenol A and phthalates) and pharmaceutical and health care products in rapid developing countries (Bouwman et al, 2012). In order to better manage toxic chemicals, in order to protect environment and human health, these EECs should be included in the monitoring and assessment program. This is especially true for the PRD, South China, one of the mega deltas in the world, and also the most developed region of China. The area has been known as "Homeland for rice and fish" in the past, but has transformed to the world centre for electronic/electrical, textile, footwear, and pharmaceutical products, in addition to its active mining industries, and overuse and abuse of fertilizers, with a wide range of toxic chemicals finding their way to our food production systems, linking with high body loadings and potential health risks, as mentioned above. In addition, uncontrolled recycling of electronic wastes also emitted a wide range of toxic chemicals, and their long-term environmental and health effects are not yet known (Chan et al, 2007; Leung et al, 2007; Wong et al, 2007).

\section{CONCLUSION}

Fish consumption is considered as the major route of exposure to $\mathrm{MeHg}$, although inhalation of elevated concentrations of gaseous elemental $\mathrm{Hg}$ is also a health risk. At the global scale, reduction of $\mathrm{Hg}$ contamination would require sustained national and international commitments over a longer period of time, from decades to centuries. Any effective strategy for reducing $\mathrm{Hg}$ exposures would require an examination of the complete life cycle of $\mathrm{Hg}$, paying attention to regional sources and fates of $\mathrm{Hg}$, and dietary exposure of coastal communities. Reduction of anthropogenic $\mathrm{Hg}$ emissions pays an important role for minimizing biotic exposure to $\mathrm{MeHg}$ and associated human health risks. It is important to reduce point-source pollution, especially emissions from substandard coal-fired power plants, and intentional usages such as $\mathrm{Hg}$ compounds used in vaccines, and fluorescent lights. It is also essential to avoid $\mathrm{Hg}$ methylation in sediment of freshwater fish ponds and sediment beneath or close to marine fish culture, in order to safeguard our fish products against $\mathrm{Hg}$ contamination. In terms of food safety, there seems to be an urgent need of establishing a regional list of toxic chemicals for more efficient control, focusing on PTS commonly found in local food items.

\section{ACKNOWLEDGEMENTS}

The author thanks all colleagues and postgraduate students, who have involved in the research project on $\mathrm{Hg}$, sponsored by the Collaborative Research Fund (CRF), of Research Grants Council (RGC) of Hong Kong. Financial support from the Hong Kong Institute of Education for the seed fund 


\section{for newly appointed Professors and Chair Professors is also gratefully acknowledged.}

\section{REFERENCES}

Austin D (2008) An epidemiological analysis of the 'autism and mercury poisoning' hypothesis. Int J Risk Saf Med 20: 135-42.

Axelrad DM, Atkeson TD, Lange T, Pollman CD, et al (2007). Chapter 3B: Mercury Monitoring, Research and Environmental Assessment in South Florida. In: South Florida Environ Report, Vol I. South Florida Water Management District \& Florida Department of Environmental Protection, USA.

Axelrad DM, Bellinger DC, Ryan LM, Woodruff TJ (2007b). Dose-response relationship of prenatal mercury exposure and IQ: An integrative analysis of epidemiologic data. Environ Health Perspect. 115: 609-15.

Bailey M (2013). "Minamata Convention on Mercury". United States Environmental Protection Agency. Retrieved Feb 5, 2016.

Baker JP (2008). Mercury, vaccines, and autism: One controversy, three histories. Am J Public Health 98: $244-53$

Bartlett ES, Trasande L (2013). Economic impacts of environmentally attributable childhood health outcomes in the European Union. European J Public Health 24: 21-6.

BBC News (2013) British Broadcast Company. China acknowledges "cancer villages". 22 Feb 2013. http://www.bbc.com/news/world-asia-china-21545868

Benoit JM, Gilmour CC, Mason RP (2001). The influence of sulfide on solid-phase mercury bioavailability for methylation by pure culture of Desulfobulbus propionicus (1pr3). Environ Sci Technol 35: 127-32.

Bloom NS (1992) On the chemical form of mercury in edible fish and marine invertebrate tissue. Can J Fish Aquat Sci 49:1010-7.

Bouwman H, MH Wong, R Barra (2012). GEF Guidance on Emerging Chemicals Management Issues in Developing Countries and Countries with Economy in Transition. UNEP/GEF.

Briggs D (2003) Environmental pollution and the global burden of disease. Br Med Bull 68: 1-24.

Cancer Fund (2015) Latest Cancer Statistics. http://www.cancer-fund.org/en/cancer-statistics.html

CCME (2006). Canada-wide standards for mercury emissions from coal-fired electric power generation plants. Canadian Council of Ministers of the Environment.

CFS (2008). Mercury in fish and food safety. Centre for Food Safety. $22^{\text {nd }}$ Issue (May, 2008). Hong Kong SAR Government.

Chalmers AT, Argue DM, Gay DA, Brigham ME, Schmitt CJ, Lorenz DL (2011). Mercury trends in fish from rivers and lakes in the United States, 1969-2005. Environ Monit Assess 175: 175-91.

Chan JKY, GH Xing, Y Yu, Y Liang, LX Chen, SC Wu, CKC Wong, CKM Leung, MH Wong (2007). Body loadings and health risk assessment of polychlorinated dibenzo- $p$-dioxins and dibenzofurans at an intensive electronic waste recycling site in China. Environ Sci Technol 41: 7668-74.

Chan WF, H Li, FY Wu, SC Wu, MH Wong (2013). Arsenic uptake in upland rice inoculated with a combination or single arbuscular mycorrhizal fungi. J Hazard Mater 262: 1116-22.

Chaney RL (2012). Food safety issues for mineral and organic fertilizers. Advances in Agron. 117: 51-116.

Chen C (2011). The ecotoxicology of methylmercury: A transdisciplinary challenge. Ecohealth 5: 393-5. 
Cheng Z, Man YB, Nie XP, Wong MH (2013a). Trophic relationships and health risk assessments of trace metals in the aquaculture pond ecosystem of Pearl River Delta, China. Chemosphere 90: 2142-8.

Cheng Z, Chen KC, Li KB, Nie XP, Wu SC, Wong CKC, Wong MH (2013b) Arsenic contamination in the freshwater fish ponds of Pearl River Delta: Bioaccumulation and health risk assessment. Environ Sci Pollut Res 20: 4484-95.

Cheng Z, Nie XP, Wang HS, Wong MH (2013c). Risk assessments of human exposure to bioaccessible phthalate esters through market fish consumption. Environ Intl 57-58:75-80.

Cheung KC, HM Leung, MH Wong (2007a). Metal concentrations of common freshwater and marine fish from the Pearl River Delta, South China. Arch Environ Contam Toxicol 54: 705-15.

Cheung KC, HM Leung, KY Kong, MH Wong (2007b). Residual levels of DDTs and PAHs in freshwater and marine fish from Hong Kong markets and their health risk assessment. Chemosphere 66: 460-8.

Cheung KC, JS Zheng, HM Leung, MH Wong (2008). Exposure to polybrominated diphenyl ethers associated with consumption of marine and freshwater fish in Hong Kong. Chemosphere 70:1707-20.

China Real Time (2015) Pollution: Causing lung cancer in China?

http://blogs.wsj.com/chinarealtime/2014/03/10/does-air-pollution-cause-cancer/

Clarkson TW, Magos L, Myers GJ (2003). The toxicology of mercury - Current exposures and clinical manifestations. N Engl J Med 349: 1731-7.

Davidson PW, Myers GJ, Weiss B (2004). Mercury exposure and child development outcomes/ Pediatrics 113 (4 Suppl): 1023-9.

Davison PW, Leste A, Benstrong E, Valentin J, et al (2000). Fish consumption, mercury exposure, and their associations with scholastic achievement in the Seychelles Child Development Study. Neurotoxicol 31: 439-47.

Depew DC, Burgess NM, Campbell LM (2013). Spatial patterns of methylmercury risks to common loons and piscivorous fish in Canada. Environ Sci Technol 47: 13093-03.

Dickman MD, Leung KMC (1998) Mercury and organochlorineexposure from fish consumption in Hong Kong. Chemosphere 37: 991-1015.

Dickman MD, Leung CK, Leong MK (1998) Hong Kong male sub fertility links to mercury in human hair and fish. Sci Tot Environ 214: 165-74.

Environmental Working Group (2005) Body burden: The pollution newborns.

http://www.ewg.org/research/body-burden-pollution-newborns Retrieved 8 Jan 2016.

Fang GC, Nam DH, Basu N (2011). Mercury and selenium content of Taiwanesse seafood. Food Add Contam: Part B: Surveillance 4: 212-7.

Fok TF, Lam HS, Ng PC, Yip AS, Sin NC, Chan IH, Gu GJ, So HK, Wong EM, Lam CW (2007). Fetal methylmercury exposure as measured by cord blood mercury concentrations in a mother-infant cohort in Hong Kong. Environ Int. 33: 84-92.

Harada M (1972) Minamata Disease. Kumamoto Nichinichi Shinichi Shinbun Centre \& Information Center/Iwanami Shoten Pub. Tokyo, Japan.

Harada M (1995). Minamata disease: Methylmercury poisoning in Japan caused by environmental pollution. Crit Rev Toxicol 25 1-24.

Harris RC, Rudd JWM, Amyot M, et al (2007). Whole-ecosystem study shows rapid fish-mercury response to 
changes in mercury deposition. Procc Nat Acad Sci USA 104: 16586-91.

Hong Kong Cancer Registry (2013). Top Cancers in 2013. Hospital Authority, Hong Kong.

Hu JL, FY Wu, SC Wu, ZH Cao, XG Lin, MH Wong (2013) Bioaccessibility, dietary exposure and human risk assessment of heavy metals from market vegetables in Hong Kong revealed with an in vitro gastrointestinal model. Chemosphere 91: 455-61.

HKEPD (2016). Toxic substances monitoring in Hong Kong. Environmental Protection Department.

http://www.epd.gov.hk/epd/mobile/english/environmentinhk/water/marine quality/Tox details.html

Huang YQ, Wong CKC, Zheng JS, Bouwman H, Barra R, Wahlstrom B, Neretin L, Wong MH (2012) Bisphenol A (BPA) in China: A review of sources, environmental levels, and potential human health impacts. Environ Int 42: 91-9.

Hylander LD, Goodsite ME (2006). Environmental costs of mercury pollution. Sci Tot Environ 368: 352-70.

INC (2014). Sixth Session of the Intergovernmental Negotiating Committee on Mercury (INC), Minamata Convention on Mercury. United Nation Environmental Program.

\section{http://www.mercuryconvention.org/Negotiations/INC6/tabid/3563/Default.aspx}

Jackson AK, Evers DC, Etterson MA, Condon AM, Folsom SB, Detweiler J, Schmerfeld J, Cristol DA. (2011). Mercury exposure affects the reproductive success of a free-living terrestrial songbird, the Carolina wren (Thryothorus ludovicianus). Auk 128: 759-69.

JEFCA (1993). Evaluation of certain food additives and contaminants. Joint Food and Agriculture Organization/World Health Organization. Expert Committee on Food Additives. Technical Report Series: 837. WHO, Geneva, Switzerland.

JECFA (2000). Safety evaluation of certain food additives and contaminants. Joint Food and Agriculture Organization/World Health Organization. $53^{\text {rd }}$ Expert Committee on Food Additives. Series: 44: Methylmercury. WHO, Geneva, Switzerland.

Jedrychowski W, Perera F, Jankowski J, et al (2007). Fish consumption in pregnancy, cord blood mercury level and cognitive and psychomotor development of infants followed opver the first 3 years of life: Krakow epidemiologic study. Environ Int 33: 1057-62.

Ko LYY, Qin YY, Wong MH (2012) Heavy metal overloads and autism in children from mainland China and Hong Kong: a preliminary study. In: Environmental Contamination - Health Risks and Ecological Restoration. Wong MH (Ed) Taylor and Francis/CRC, London.

Krishnasamy V, Otte J, Silbergeld E (2015) Antimicrobial use in Chinese swine and broiler poultry production. Antimicro Resist Infect Control 4: 17, doi:10.1186/s13756-015-0050-y

Lamborg CH, Fitzgerald WF, Damman AWH, Benoit JM, Balcom PH, Engstrom DR (2002). Modern and historic atmospherice mercury fluxes in both hemispheres: Global and regional mercury cycling implications. GI Biogeochem Cycles 16: 1104-10.

Lebel J (2003). Health: An ecosystem approach. International Development Research Centre, Ottawa, Canada.

Leung AOW, WJ Luksemburg, AS Wong, MH Wong (2007). Spatial distribution of polybrominated diphenyl ethers and polychlorinated dibenzo-p-dioxins and dibenzofurans in soil and combusted residue at Guiyu, an e-waste recycling site in SE China. Environ Sci Technol 41: 2730-7. 
Leung SY, CK Kwok, XP Nie, KC Cheung, MH Wong (2010) Risk assessment of residual DDTs in freshwater and marine fish cultivated around the Pearl River Delta, China. Arch Environ Con Tox 58: 415-30.

Liang P, DD Shao, SC Wu, JB Shi, FY Wu, SCL Lo, WX Wang, MH Wong (2011) The influence of mariculture on mercury distribution in sediments and fish around Hong Kong and adjacent mainland China waters. Chemosphere 82: 1038-43.

Liang P, Lam CL, Wang HS, Shi JB, Wu SC, Wang WX, Zhang J, Wang HL, Wong MH (2013a). Formation and distribution of methylmercury in sediments on a mariculture site: A mesocosm study. J Soil Sediment 13: 1301-8.

Liang P, Qin YY, Zhang C, Zhang J, Cao YC, Wu SC, Wong CKC, Wong MH (2013b).Plasma mercury levels in Hong Kong residents: in relation to fish consumption. Sci Total Environ 463-464: 1225-9.

Liu L (2010). Cancer village: Made in China. Environment: Science and Policy for Sustainable Development. March/April 2010.

Liu JL, MH Wong (2013) Pharmaceuticals and personal care products (PPCPs): A review on environmental contamination in China. Environ Intl 59: 208-24.

Man YB, Chow KL, Man M, Lam JCW, Lau FTK, Fung WC, Wong MH (2015). Profiles and removal efficiency of polybrominated diphenyl ethers by two different types of sewage treatment work in Hong Kong. Sci Tot Environ 505: 261-8.

Man YB, Wu SC, Wong MH (2014). Shark fin, a symbol of wealth and good fortune may pose health risks: The case of mercury. Environ Geochem Health 36: 1015-27.

Mason RP (2009). Mercury emissions from natural processes and their importance in the global mercury cycle. In: Mercury Fae and Transport in the Global Atmosphere. Ed. Pirrone N, Mason RP. Springer, Dordrecht.

METAALICUS (2010). The METALLICUS project.

http://wi.water.usgs.gov/mercury/metaalicus-project.html. Retrieved 18 Jan 2016.

Miyake K, Hirasawa T, Koide T, Kubota T (2012) Epigenetics In autism and other neurodevelopmental diseases. Adv Exp Med Biol 724: 91-8.

NAS (2000). National Research Council Report: Toxicological effects of methylmercury. National Academic Press. Washington, DC.

Newschaffer CJ, Croen LA, Daniels J, et al (2007) The epidemiology of autism spectrum disorders. Annu Rev Public Health 28: 235-58.

Orihel DM, Paterson MJ, Gilmour CC, Bodaly RA, Hintelmann H (2007). Experimental evidence of a linear relationship between inorganic mercury loading and methylmercury accumulation by aquatic biota. Environ Sci Technol 41: 4952-8.

Pacyna EG, Pacyna JM, Steenhuisen F, Wilson SJ (2006). Global anthropogenic mercury emission inventory for 2000. Atmo Environ 40: 4048-63.

Paterson MJP. Blanchfield P, Podemski C, Hintelmann H, Harris R, Ogrinc N, Rudd JMW, Sandilands KA (2006). Bioaccumulation of newly-deposited mercury by fish and invertebrates: An enclosure study using stable mercury isotopes. Can J Fish Aquat Sci 63: 2213-24. 
Pichery C, Bellanger M, Zmirou-Navier D, Frery N, Cordier S, Roue-LeGall A, Hartemann P, Grandjean P (2012). Economic evalution of health consequences of prenatal methylmercury exposure in France. Environ Health 11: 53-62.

Pinel JPG (2011) Biopsychology. Pearson, Boston, Massachusetts.

Pirrone N, Keeler GJ, Nriagu JO (1996). Regional differences in worldwide emissions of mercury to the atmosphere. Atmos Environ 30: 2981-7.

Qin YY, Leung CKM, Leung AOW, Wu SC, Zheng JS, Wong MH (2010) Persistent organic pollutants and heavy metals in adipose tissues of patients with uterine leiomyomas and the association of these pollutants with seafood diet, BMI, and age. Environ Sci Pollut R 17: 229-40.

Qin YY, Leung CKM, Leung AOW, Wu SC, Zheng JS, Wong MH (2011). Persistent organic pollutants in food items collected in Hong Kong. Chemosphere 82: 1329-36.

Ramon R, Ballester F, Aguinagalde X, Amurrio A, Vioque J, Lacasaña M, et al. (2009). Fish consumption during pregnancy, prenatal mercury exposure, and anthropometric measures at birth in a prospective mother-infant cohort study in Spain. Am J Clin Nutr 90: 1047-55.

Ruus A, Overjordet IB, Braaten HFV, Evenset A, Christensen G, Heimstad ES, Gabrielsen GW, Borga K (2015). Methylmercury biomagnification in an Arctic pelagi food web. Environ Toxicol Chem 34: 2636-43.

Schneider L, Maher W, Green A, Vogt RC (2013). Mercury contamination in reptiles: An emerging problem with consequences for wildlife and human health. In: Mercury: Sources, Applications and Health Impacts. Ed. Kim KH, Brown RJC. Nova Sci Pub, Hauppauge. NY.

Schober SE, Sinks TH, Jones RL, Bolger PM, et al (2003). Blood mercury levels in U.S. children and women of childbearing age, 1999-2000. J Am Med Assoc, 289: 1667-74.

Shao DD, Kang Y, Wu SC, Wong MH (2012). Effects of sulfate reducing bacteria and sulfate concentrations on mercury methylation in freshwater sediments. Sci Total Environ 424: 331-6.

Shao DD, Y Kang, Z Cheng, HS Wang, MJ Huang, SC Wu, KC Chen, MH Wong (2013) Hair mercury levels and food consumption in residents from the Pearl River Delta, South China. Food Chem 136: 682-8.

Srivastava RK, Hutson N, Martin B, Princiotta F, Staudt J (2006). Control of mercury emissions from coal-fired electric utility boilers: an overview of the status of mercury control technologies, Environ Sci Technol 40: 1385-93,

Swain EB, Jakus PM, Rice G, Lupi F, Maxson PA, Pacyna JM, Penn A, Spidqel SJ, Veiga MM (2007). Socioeconomic consequences of mercury use and pollution. AMBIO 36: 45-61.

Ui J (1992). Industrial Pollution in Japan. United Nations University Press. Geneva, Switzerland.

UNEP (2010). Process optimization guidance for reducing mercury emissions from coal combustion in power plants. Division of Technology, Industry and Economics, Geneva, Switzerland.

UNEP (2013). Global mercury assessment 2013: Emissions, releases and environmental transport. UNEP Chemicals Branch, Geneva, Switzerland.

UNEP (2015). Stockholm Convention on Persistent Organic Pollutants. United Nation Environmental Program. http://www.chem.unep.ch/pops/ Retrieved 12 Feb 2016.

Unuvar E, Ahmadov H, Kiziler AR, Aydemir B, Toprak S, et al. (2007) Mercury levels in cord blood and meconium of healthy newborns and venous blood of their mothers: clinical, prospective cohort study. Sci Tot Environ. 374: 60-70. 
USCDC (2008). Mercury and vaccines (thimerosal). Center for Disease Control, USA.

USEPA (1997). Mercury study report to congress. Vol 1: Executive Summary. USEPA, EPA-452/R-97-003.

USEPA (2005) Risk-based concentration table. United State Environmental Protection Agency, Region 3, Philadelphia, PA. http://www.epa.gov/reg3hwmd/risk/human/rbc/RBCoct07.pdf

USEPA (2013) Reference dose (RfD): Description and use in health risk assessments, Background Document $1 \mathrm{~A}$, Integrated risk information system (IRIS); United States Environmental Protection Agency: Washington, DC.

USFDA (1993) Guidance documents for trace elements in seafood. United States Food and Drug Administration. Center for Food Safety and Applied Nutrition, Washington, DC

USFDA (2001). Mercury levels in seafood species. US Food and Drug Administration, Center for Food Safety and Applied Nutrition, Office of Seafood. Washington, DC.

USFDA (2008). Thimerosal in vaccines. Center for Biologics Evaluation and Research, U.S. Food and Drug Administration.

USFDA/USEPA (2004). What you need to know about mercury in fish and shellfish. Retrieved 18 Jan 2016. Ui J (1992) Industrial Pollution in Japan. United Nation Univ Press. Tokyo, Japan.

USGS (2013). The METAALICUS project. http://wi.water.usgs.gov/mercury/metaalicus-project.html US Geological Survey. Retrieved 28 Jan 2016.

Varian-Ramos CW, Swaddle JP, Cristol DA (2014). Mercury reduces avian reproductive success and imposes selection: An experimental study with adult- or lifetime- exposure in Zebra Finch. PLoS ONE 9: e95674.

Wang HS, Zhao YG, Man YB, Wong KC, Wong MH (2011a) Oral bioaccessibility and human risk assessment of organochlorine pesticides (OCPs) via fish consumption, using an in vitro gastrointestinal model. Food Chem 127: 1673-79.

Wang HS, J Du, KL Ho, HM Leung, MHW Lam, JP Giesy, CKC Wong, MH Wong (2011b) Exposure of Hong Kong residents to PBDEs and their structural analogues through market fish consumption. J Hazard Mater 192: 374-80.

Wang HS, Xu WF, Chen ZJ, Cheng Z, Ge LC, Man YB, Giesy JP, Du J, Wong CKC, Wong MH (2013) In vitro estimation of exposure of Hong Kong residents to mercury and methylmercury via consumption of market fishes. J Hazard Mater 248-9: 387-93.

Wei X, Ching LY, Cheng SH, Wong MH, Wong CKC (2010) The detection of dioxin- and estrogenic-like pollutants in marine and freshwater fishes cultivated in Pearl River Delta, China. Environ Pollut 158: 2302-9.

Wei X, Huang YQ, Wong MH, Giesy JP, Wong CKC (2011a) Assessment of risk to humans of bisphenol A in marine and freshwater fish from Pearl River Delta, China. Chemosphere 85:122-8.

Wei X, Leung KS, Wong MH, Giesy J, Cai ZW, Wong CKC (2011b) Assessment of risk of PCDD/Fs and dioxin-like PCBs in marine and freshwater fish in Pearl River Delta, China, Marine Pollut Bull 63:166-71.

WHO (1999). WHO Laboratory Manual for the Examination of Human Semen and Sperm-cervical Mucus Interaction, World Health Organization, $4^{\text {th }}$ ed. Cambridge Univ Press, Cambridge.

WHO (2014) Antimicrobial resistance: global surveillance. World Health Organization. Geneva, WHO/HSE/PED/2014.2.

Whylie P, Albaiges, Barra R, Bouwman H, Dyke D, Wania, F, MH Wong (2003). Regionally Based Assessment of Persistent Toxic Substances. Global Report. UNEP/GEF. 
Wijingaarden van E, Davidson PW, Smith TH, Evans K, Yost K, Love T, Thurston GE, Zareba G, Burns CM, Shamlaye CF, Myers GJ (2013) Autism spectrum disorder phenotypes and prenatal exposure to methylmercury. Epidemiology 24: 651-9.

Wong CSC, Duzgoren-Aydin NS, Aydin A, Wong MH (2006). Sources and trends of environmental mercury emissions in Asia. Sci Tot Environ 368: 649-62.

Wong MH, Choi K, Grosheva E, Saki S, Shibata Y, Suzuki N, Wang J, Zhou H, Leung A (2002). Regionally Based Assessment of Persistent Toxic Substances. Regional Report of Central and North East Asia. UNEP/GEF.

Wong MH, Cheung KC, Yediler A, Wong CKC (2004). The dyke-pond systems in South China: Past, present and future. In: Wetlands Ecosystems in Asia: Function and Management. Wong MH (Ed) Elsevier, Amsterdam, pp. 69-86.

Wong MH, Leung AOW, Chan JKY, Choi MPK (2005). A review on the usage of POP pesticides in China, with emphasis on DDT loadings in human milk. Chemosphere 60: 740-52.

Wong MH, SC Wu, WJ Deng, XZ Yu, Q Luo, AOW Leung, CSC Wong, WJ Lukesmburg, AS Wong (2007). Export of toxic chemicals - A review of the case of uncontrolled e-waste recycling. Environ Pollut 149:131-40.

Wong MH, MA Armour, R Naidu, M Man (2012) Persistent toxic substances: sources, fates and effects. Rev Environ Health 27: 207-13.

Wu YS, Wang DG, Streets DJ, Hao J, Chan M, Jiang J (2006). Trends in anthropogenic mercury emissions in China from 1995 to 2003. Environ Sci Technol 40: 5312-8.

Zafeiriou DI, Ververi A, Vargiami E (2007). Childhood autism and associated comorbidities. Brain 29: 257-72.

Zhang L, MH Wong (2007). Environmental mercury contamination in China: Sources and impacts. Environ Int 33: 108-21.

Zhao YG, Wan HT, Law AYS, Wei X, Huang YQ, Giesy J, Wong MH, Wong CKC (2011) Risk assessment for human consumption of perfluorinated compound-contaminated freshwater and marine fish from Hong Kong and Xiamen. Chemosphere 85: 277-83.

Zhao YG, Wong CKC, Wong MH (2012) Environmental contamination, human exposure and body loadings of perfluorooctane sulfonate (PFOS), focusing on Asian countries. Chemosphere 89: 355-68.

Zheng JS, Jiao LP, Leung AOW, Huang YQ, You TT, Wong MH (2012) Polybrominated diphenyl ethers (PBDEs) in China - sources, trends and their adverse impacts on human health. In: Environmental Contamination - Health Risks and Ecological Restoration. Wong MH (Ed) Taylor \& Francis/CRC, London.

Zhang S (2013) Pig-manure fertilizer linked to human MRSA infections. Nature 2013: 13752.

Zhou HY, Wong MH (2000). Accumulation of sediment-sorbed PCBs in tilapia. Water Res 34: 2905-2914. 